\title{
Overview Environmental Danger of Eroided Land in Azerbaijan and Their Solutions
}

\author{
RAE ZH Aliyev* \\ Erosion and irrigation Institute of the Azerbaijan National Academy of Sciences, Azerbaijan
}

*Corresponding author: Rae ZH Aliyev, Erosion and irrigation Institute of the Azerbaijan National Academy of Sciences, Azerbaijan

Submission: 海 April 05, 2017; Published: 海 June 22, 2018

\begin{abstract}
The article considers the natural and economic climate and agro-climatic conditions, the geological structure, the soil-vegetation cover of the mountain-irrigated zone of Azerbaijan in the example of individual areas where the natural moisture content of soils is strongly tested, in the presence of an acute lack of field water and an uneven distribution of atmospheric precipitation. At the same time, in the region, traditional methods of surface watering in agricultural production for intensifying development have been widely differentiated: various kinds of erosion (like irrigation, water, razhnye etc.) in the erosion region. The soil productivity indicators and the potential risk of erosion in the vertical zone are predetermined, as well as the problems of preventing the danger of these types of degraded soils.
\end{abstract}

Keywords: Erosion; Degradation; Ravine; Beams; Soil fertility; Topography; Soil moisture

\section{Introduction}

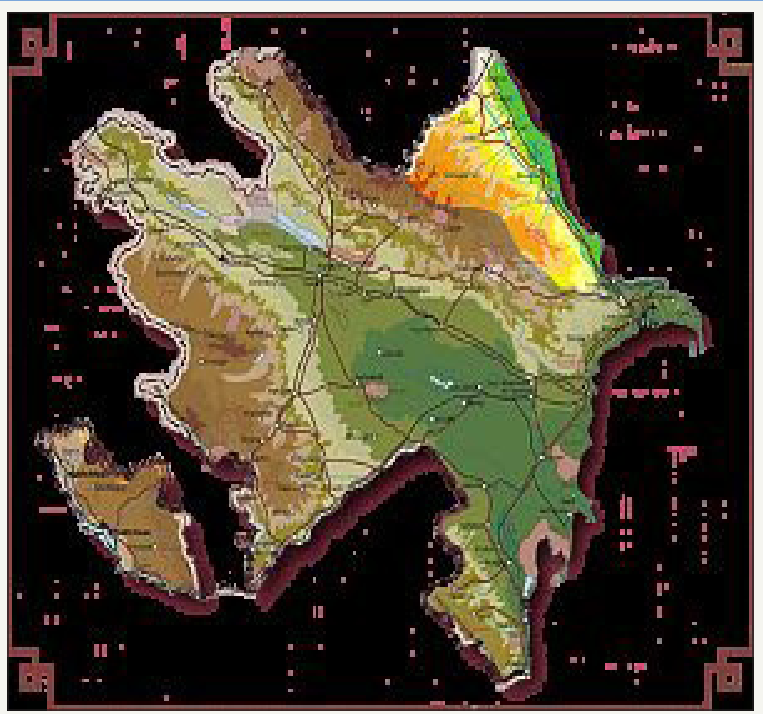

Figure 1

Mountain-Irrigat the article considers the natural and economic climate and agro-climatic conditions, the geological structure, the soil-vegetation cover of the mountain-irrigated zone of Azerbaijan in the example of individual areas where the natural moisture content of soils is strongly tested, in the presence of an acute lack of field water and an uneven distribution of atmospheric precipitation. At the same time, in the region, traditional methods of surface watering in agricultural production for intensifying development have been widely differentiated: various kinds of erosion (like irrigation, water, razhnye etc.) in the erosion region. The soil productivity indicators and the potential risk of erosion in the vertical zone are predetermined, as well as the problems of preventing the danger of these types of degraded soils. ed Zones of Azerbaijan, as well as a number of other areas of the Republic has complicated natural conditions, where widespread subalpine and alpine meadows, with huge environmental and climatic forest 
values, as well as extending broad arable lands that are under the influence of natural and anthropogenic factors, to varying degrees, affected by erosional processes Figure 1 .

Summer pastures subalpine meadows in connection with weak grass overgrazing, especially in early spring, are the major cause of erosion, which not only quantitatively but also qualitatively damage soil cover, washing away the fertile upper humus layer forming on the slopes of estimation-girder network.

In connection with the development of animal husbandry in the Republic, at this stage, the protection of mountain meadows, creating a sustainable food supply, study their demands for nutrients, are particularly relevant where Guba-Khachmaz zones with a total area $8840 \mathrm{~km}^{2}$, located on the southern slopes of the Greater Caucasus, has considerable potential in the development of forage Summer pastures of this zone are mainly low mesophilous vegetation grass family, which also represented along with Fescue grassland (Festura L), etc. Agriculture in these areas leading crop raising is gardening, wine growing, melon production, vegetable production Cereals sown mainly winter wheat bread, and industrial crops - tobacco, sunflower. Another difference of the Guba-khachmaz region is the large number and variety of medicinal plants growing here. In mountain forests and meadows PA grow Valerian, ephedra, lazurnik, tamus, Hawthorn, Solomon's seal, Juniper, Balsam, nightshade, Epilobium, Geum, borodovnik, plantain, Altea, letter, Pimpinella, elder, dushevnik and many other chain plants.

The aim of our research is to conduct a comprehensive analysis of a number of environmental factors that contribute to erosion, establish the extent of the damage, soil fertility and identifying the best ways to resolve, the protection and restoration of fertility. In the geological and geomorphologic region has a fairly complex structure, where the high mountains and steep slope alternate Foothill areas and Plains, which in turn contributes to the development of a fairly Motley then diversity climate vegetation cover. [1]. The complexity of the geomorphologic structure, the presence of steep slopes, as well as anthropogenic forcing has a significant value of intensity of runoff, which in turn reinforces the development of erosive processes, resulting in created wide ravines, which are presented in the final stage beams, changing the appearance of the geomorphologic zones in General. Highlands is located at an altitude of 2000-3466 m above sea level. Relief is represented strongly dissected erosion-denudacionnoj form. Soil formation rocks are primarily composed of clays, limestones and Shales. For this zone is characterized by intense mudslides, causing considerable environmental damage Wednesday, especially in the destruction of soil fertility.

Srednegornaja region is located at an altitude of $1000-2000 \mathrm{~m}$ above sea level and is characterized by the presence of the dome and the initiation of the watershed. The mountain slopes are heavily fragmented and dominated by erosion-denudacionnyj relief. Soil formation rocks are represented slates, limestones and sands are basalt, hydromica, andesites, etc. Lowlands is located between izogipsami $600-1000 \mathrm{~m}$ above sea level. The surface is represented by the narrow lap islets separated by wide valleys between them. The soils formed in deposits 3 (Paleogene, Neogene) and 4-tichnogo Cenozoic period. The flat area is located at an altitude of $200-600 \mathrm{~m}$ above sea level, where mostly alluvial-proljuvialnye deposits, which developed fertile soil, intensively used in agriculture. In Quba-Khachmaz zone E.M. Shikhlinski [1] distinguishes 3 types of climate:

1) Moderately warm, typical for lowland regions in area with relatively mild winters;

2) Moderately warm moist type with a uniform distribution of rainfall throughout the year, covers part of the foothill zone and

3) Cold climate with wet winters, characteristic of the foothills and mountain areas. Minimum air temperature $0.5^{\circ}$ with falls in January, and the maximum in $23.6^{\circ} \mathrm{c}$ in the month of July.

The average soil temperature ranges from $-1^{\circ} \mathrm{p}-30.7{ }^{\circ} \mathrm{c}$. Minimum temperature of soil in $-1^{\circ}$ with falls on January, maximum $30.0^{\circ} \mathrm{C}$ (July) and August $30.7^{\circ}$ months. The surface temperature of the soil determines the intensity of the biochemical processes taking place in the soil, and intrasoil, temperature has a significant impact on microbiological processes occurring in the soil profile. Annual rainfall varies from an increase in the level of hypsometric and meets not plain $939 \mathrm{~mm}$ and $1400 \mathrm{~mm}$ in the Highlands. The average relative air humidity is $71 \%$ hesitated on the time of year from 59 to $87 \%$. In hydro geographic against rivers Guba-Khachmaz zones are characterized by a mudslide. The source of the rivers of the region on the main Caucasian Ridge.

The hydrographic network of the zone is very developed; there are about 60 minute Mountain Rivers. The largest is the Samur, Gusarchay, Garachay, Gudialchay, Velvelichay, Devechichaj, Gilgilchay, are flowing In from the South-West to the North-East and flow into the Caspian Sea. These rivers with sleeves, especially on steep slopes erode soils under forest and meadow formations that particularly intense during long and intense rainfall [1]. Change of temperature and precipitation on vertical zonality, contributes to the natural change in species composition of the ground vegetation, which are divided into 3 zones:

a) Alpine and subalpine grasslands

b) mountain-meadow

c) plain

The first Botanic research in Quba-khachmaz region N.i.kuznetsov was carried out later a. Aliyev SDR. Alpine meadows here are mainly members of the cereals and legumes (Adonis are found here. Coronaria L.), cow parsnip (Heracleum L.), chebrets (Thymus L.), zizifora (Ziziphora (L)) [2].

Subalpine meadows located at an altitude of $1800-2600 \mathrm{~m}$ presented multi-year mesophilous vegetation and are widely used as summer pastbishh. In the forest zone meet oak (Quercus L.), hornbeam (Carpinus L.), wild chestnut (Castanea Mill) Walnut 
(Juglans regia), hazelnuts (), Mespilus (Mespilus L.), and on the plains of Elm (Ulmus L), poplar (Populus L.), plantain (Plantago L.), BlackBerry, mozhzhevilnik (Juniperus L), sedge (Carex L), derzhiderevo (Paliurus spina christi) Wild pomegranate and shrubs. Research of several scientists soil cover, their genesis, the geographical distribution of the southern slopes of the Greater Caucasus were continued on the basis of large-scale maps 1:10000 and 1:50000, a map of the current status of the soils of the major Caucasus 1:100000 scale, held the State Cadastre and monograph of modern soil condition of the big Caucasus [3,4], where the main soil types and subtypes of the Guba-khachmaz region:

\section{1) Nepolnorazvitye mountain-meadow (Dystric Regosols)}

2) Tightly Greensward mountain meadow (Dystric Regosols)

3) Loose sod mountain meadow (Dystric Regosols)

4) Leached Brown mountain-forest (Eutric Combisols)

5) Ostepnennye mountain Brown (Chromic Combisols)

6) Meadow-forest (Umbric Leptisols)

7) Alluvial meadow (Eutric Fluvisols)

Nepolnorazvitye mountain meadow soils are located on the territory of summer pastures and cover a large area. The relief of the territory consists of slopes with South-western slope. Places are found outcrops of rocks. The soil is mostly low-power with extremely rare vegetation. Granulometric composition of the soil medium loamy with physical clay content $(<0.01 \mathrm{~mm}) 33.28 \%$ and silt $(<0.001 \mathrm{~mm}) 6.44 \%$. In connection with the scarce and sparse vegetation, amount of humus is $2.14 \%, 0.13 \%$ of total nitrogen, total phosphorus $0.21 \%$. The amount of sequestered grounds is $30.10 \mathrm{mg} / \mathrm{EQ}$. the $100 \mathrm{gr}$. soil. In the complex grounds sequestered the main share of Sa, representing $25.7 \mathrm{mg} / \mathrm{EQ}$ with $\mathrm{m}(\mathrm{g})$ is $7.2 \mathrm{mg} / \mathrm{EQ}$ and hydrogen $6.6 \mathrm{mg} / \mathrm{EQ}$ at $100 \mathrm{~g}$ soil. Tight turf mountain meadow soils located on different parts of the summer pastures. Introducing the Meadow vegetation vegetation, established a dernennyj layer on the soil surface. In most parts of the soil being shallow, where horizon and formed the maternal breed. Granulometric composition of soil heavy loam, with physical clay $(<0.01 \mathrm{~mm}) 44.40 \%$, and silt fractions $(<0.001 \mathrm{~mm}) 8.12 \%$.

Rich vegetation has contributed to a sharp increase in humus, which is indicated by the high value of humus, at $11.53-15.31 \%$. Total nitrogen and phosphorus, respectively amounted to 0.58 and $0.38 \%$. The amount of sequestered grounds is rather high, amounting to $29.00-36.00 \mathrm{mg} / \mathrm{EQ}$ on $100 \mathrm{~g}$ of soil. The complex is dominated by the Sa, accounting for $19.6-25.4 \mathrm{mg} / \mathrm{EQ} \mathrm{Mg} 4.8$ $6.6 \mathrm{mg} / \mathrm{EQ}$, and hydrogen 4.6-5.9 mg/EQ at $100 \mathrm{~g}$ soil. High hydrogen values associated with acidic Wednesday $(\mathrm{pH}=5.2)$. Loose sod mountain meadow soils are formed on the summer pastures $8.28 \%$ of the total area. The terrain consists of slopes of different exposure and wide ravines, pastures and bushes. Morphological description profile, upper horizons having Brown colouring, svetleja to the lower horizons and having light brown and komkovatuju structure.

In connection with the leaching of the soil does not boil Granulometric composition of the soil is heavy clay, with physical clay $(<0.01 \mathrm{~mm}) 42.06-32.36 \%$ and physical silt $(<0.001 \mathrm{~mm})$ $-13.963 .00 \%$. Hygroscopic moisture soft sod mountain-meadow soils ranges from $-4.02 .0 \%$, the amount of humus varies widely from $17.80 \%$ up to 8.25 that characterizes these soils as vysokogumusirovannye. Values of total nitrogen and phosphorus in soil profile varies accordingly, -0.65 and $0.52-0.290 .21 \%$. The amount of sequestered grounds is $23.24-21.20 \mathrm{mg} / \mathrm{EQ}$ on $100 \mathrm{~g}$ of soil. Bioclimatic conditions promote not the full breakdown of organic substances, and therefore the accumulation of humus. Mountain meadow soils Greensward on granulometric composition clayey and loamy. The content of physical clay in soil leached not $42.80-62.20 \%$, medium leached $32.60-60.00 \%$. Soil data are structural.

Bulk density on soil profile-1.10 $0.96 \mathrm{~g} / \mathrm{cm}^{3}$ and minimum values gets on the derninnom layer. On not leached soil bulk density profile ranges from $2.18-2.72 \mathrm{~g} / \mathrm{cm}^{3}$, medium leached $2.91-3.12 \mathrm{~g} /$ $\mathrm{cm}^{3}$. The total fenestration on the upper horizons are not leached soils $69-71 \%$ and evaluated as rocks. According to Mamedova G.Sh. [5] on the basis of bonitirovochnyh calculations, highest score 90 falls on the mountain-forest Brown cultivated soils, occupying more $0.70 \%$ for the country as a whole. Also a high scores table got mountain meadow turf soils-89 forest and meadow soils-86.

Lowest in 20 points received mountain-meadow primitive and median values in 63 points long meadow (alluvial Meadow) [3]. Erosive processes as one of the factors exogenous forces, plays a significant role in shaping the landscape as a whole. Regardless of terrain changes, forest areas and territories covered with grassy vegetation and erosive processes manifest themselves very poorly, as the decisive factor in preventing erosion processes is the vegetation. Erosive processes are particularly apparent in the territories with low vegetation [6]. Human impact on the environment Wednesday, cultivating crops on slopes, ploughing along the slopes, intensive development of pastures, deforestation, etc. are the main factors which have increased erosion and soil degradation, respectively. Resulting in a takeaway of the upperhumified the horizon. Deterioration of the physical properties of soils, especially the water permeability of the soil, which contributes to runoff, as well as stems the enriched super-heated particles [6].

Overgrazing on summer pastures and pastures, especially in early spring, promotes the destruction of dernavoi soil, thereby creating a furrow, which in turn increases erosion of meadows. On steep slopes the soil being low, easily is exposed to erosion, resulting in a maternal breed comes to the surface, which accelerated degradation. On the plowed furrows in the accumulated water slopes sharply worsens physical properties of soils and contributes to the development of beam erosion. In addition to the debris phenomena on the southern and North-eastern slopes of the Greater Caucasus is widespread landslides, which also cause significant damage to the national economy [7].

\section{Conclusion}

Analyzing the above it is necessary to note the fact that with the development of erosive processes, Republic annually loses tens of thousands of tons of agricultural products, and therefore timely 
implement counter-erosion activities and integrated its application is considered necessary, up-to-date problem of the day.

\section{References}

1. Shikhlinski Em Climate in Azerbaijan, Baku 1968, with 341

2. Kuznetsov Ni (1909) Principles of dividing the Caucasus to Botanicogeographical province areas. Imperat EN t. l. 24

3. Prilipko li, Rodin le (1972) Mailov em-vegetation Dynamics of mountain forest meadows of the Greater Caucasus, Azerbaijan SSR, Baku, Azerbaijan.
4. Mammadov GSh (2000) State land cadastre of the Republic of Azerbaijan: legal, scientific and practical issues. Baku, Azerbaijan p. 445.

5. Mamedov GSh (2000) Land reform in Azerbaijan: legal, scientific and environmental issues. Baku, Azerbaijan, p. 371

6. Mustafayev HM (1975) Development of erosion processes on the southern slopes of the Greater Caucasus and the basis of dealing with them. Baku, Azerbaijan, p. 226.

7. Babayev M The map of the current status of the soils of the big Caucasus 1:100000 scale under Ma.

\section{(c) International License}

For possible submissions Click Here

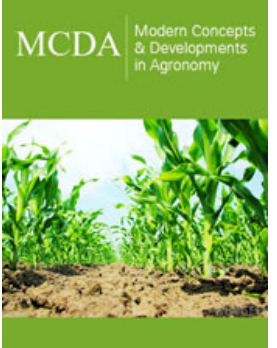

Modern Concepts \& Developments in Agronomy

\section{Benefits of Publishing with us}

- High-level peer review and editorial services

- Freely accessible online immediately upon publication

- Authors retain the copyright to their work

- Licensing it under a Creative Commons license

- Visibility through different online platforms 